\title{
Weed Management in Cotton ${ }^{1}$
}

\author{
J. A. Ferrell, G. E. MacDonald, and P. Devkota ${ }^{2}$
}

Successful weed control is essential for economical cotton production. Weeds compete with cotton for moisture, nutrients, and light. The greatest competition usually occurs early in the growing season up to 8 weeks after emergence. Late-season weeds, while not as competitive as early-season weeds, may interfere with insecticide applications, cause harvesting difficulties, and add seed to the soil seedbank.

\section{Crop Rotations}

Crop rotations are an important part of a good cotton weed control program. Certain weeds, especially nutsedges, may be less difficult to control in a preceding crop such as peanut. Other benefits of crop rotation may include reduction in insect, disease, and nematode problems both in cotton and succeeding crops.

\section{Cultivation}

Cultivation can be utilized if effective weed control is not achieved with herbicides. However, if weeds have been controlled with herbicides, there is generally little benefit from cultivation. If cultivation is needed, avoid throwing soil around small cotton plants to minimize disease problems.

\section{Herbicides}

Herbicides are the most effective means of controlling weeds in cotton. However, herbicides need to be appropriate for the weed problem in order to be effective. Therefore, before purchasing an herbicide, you should first scout the field, identify the weed, and assess the severity of the weed problem. Once these have been determined, Tables 4, 5, and 6 can help in herbicide selection for your particular situation/production system.

Preplant and/or preemergence (PRE) applications are important to ensure that the cotton has the initial competitive advantage over the weeds. Postemergence (POST) directed applications can then be utilized to extend the weed control throughout the season. The herbicides listed in Table 1 are those that have performed well in trials conducted at the UF/IFAS West Florida Research and Education Center (Jay), the Gainesville area, and the UF/IFAS North Florida Research and Education Center (Quincy and Marianna).

\section{Herbicide Application}

Calibrate spray equipment accurately. Rates too high may injure the crop, and rates too low may not provide adequate weed control. This is especially critical with banded applications, which are often utilized in cotton. Follow all label

1. This document is SS-AGR-04, one of a series of the Agronomy Department, UF/IFAS Extension. Original publication date January 2000. Revised April 2020. Visit the EDIS website at https://edis.ifas.ufl.edu for the currently supported version of this publication.

2. J. A. Ferrell, professor, Agronomy Department; G. E. MacDonald, professor, Agronomy Department; and P. Devkota, assistant professor, Agronomy Department, UF/IFAS West Florida Research and Education Center; UF/IFAS Extension, Gainesville, FL 32611. Original written by J. A. Tredaway and B. J. Brecke; revised by P. Devkota.

The use of trade names in this publication is solely for the purpose of providing specific information. UF/IFAS does not guarantee or warranty the products named, and references to them in this publication do not signify our approval to the exclusion of other products of suitable composition. All chemicals should be used in accordance with directions on the manufacturer's label. Use herbicides safely. Read and follow directions on the manufacturer's label.

The Institute of Food and Agricultural Sciences (IFAS) is an Equal Opportunity Institution authorized to provide research, educational information and other services

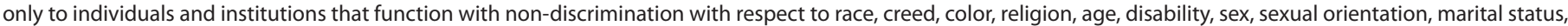

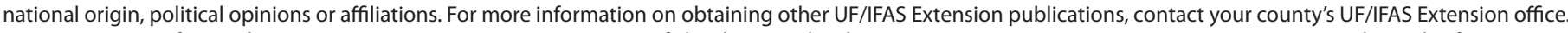
U.S. Department of Agriculture, UF/IFAS Extension Service, University of Florida, IFAS, Florida A \& M University Cooperative Extension Program, and Boards of County Commissioners Cooperating. Nick T. Place, dean for UF/IFAS Extension. 
instructions and precautions carefully. Make sure that the application is properly timed in relation to the crop and weed growth stages. Do not allow spray to drift to sensitive crops. Store herbicides behind locked doors in their original containers with intact labels, and keep them separated from seed, fertilizer, and other pesticides.

It is very important to have a clean spray system prior to spraying any crop. After each use, rinse the system thoroughly and use a tank cleaner solution to ensure that no herbicide residue remains. See EDIS document SS-AGR-102, Calibration of Herbicide Applicators (https:// edis.ifas.ufl.edu/wg013), for more information on cleaning spray equipment. If products containing dicamba or 2,4-D herbicides are applied, follow the proper sprayer clean-out procedure listed on the product label. Failure to clean spray equipment properly can result in significant damage to the sensitive crops in subsequent spray application.

\section{Hooded Sprayers}

Use of nonselective herbicides applied with a hooded sprayer may be desirable for row middles. Care should be taken to avoid contact with the crop. A residual-type herbicide may be used and will extend weed control, which may delay layby herbicide applications.

\section{Herbicide-Tolerant Cotton}

\section{Liberty Link}

Liberty Link cotton is a technology that allows the application of Liberty herbicide, glufosinate, over the top of green foliage. Glufosinate is completely different from glyphosate. Glufosinate inhibits glutamine synthase enzymes, and toxic levels of ammonia quickly accumulate in plant tissues. This process is radically different from Roundup Ready technology. Applications of Liberty to Roundup Ready cotton will result in death of the crop. Likewise, glyphosate cannot be safely applied to Liberty Link cotton.

\section{APPLICATION TIMING}

The Liberty Link cotton allows an effective broadleaf herbicide to be applied postemergence over the top of cotton. Liberty 280 can be applied to Liberty Link cotton from emergence until early bloom. A spray volume of 15 gallons/A or more with an operating pressure of $40 \mathrm{psi}$ or greater is recommended for use with flat fan nozzles. It may be applied postemergence without visible crop injury, yield reduction, or delay in maturity. No more than $80 \mathrm{oz} / \mathrm{A}$ can be applied per growing season. Liberty Link cotton cannot legally be grown south of Tampa, Florida (Route 60).

\section{HERBICIDE PROGRAM}

Liberty has no soil residual activity and only controls weeds that have emerged at the time of application. A traditional preplant-incorporated or preemergence herbicide, such as Prowl, Treflan, or Cotoran, may be needed to enhance the level of weed management. The suggested use rate for Liberty 280 is $23-43 \mathrm{oz} / \mathrm{A}$, depending on weed size and species. No more than $43 \mathrm{oz}$ per application, or $87 \mathrm{oz}$ per season, may be applied to cotton. See the label for weed size and rate information. Liberty may be applied from emergence to early bloom. Cultivation should be delayed 5 to 7 days following application. Liberty is rainfast in 4 hours. Therefore, if rain is imminent, applications of Liberty should be delayed. Ammonium sulfate at $3 \mathrm{lb} / \mathrm{A}$ has been shown to enhance the activity of Liberty (Table 2).

Liberty provides fair to good grass activity, so applications should target grasses that are 3-6 in high. Postemergence grass control can be supplemented by several postemergence grass herbicides, but these should not be tank-mixed with Liberty 280. For other difficult-to-control weeds, such as pigweeds, Liberty may be tank-mixed with Staple.

${ }^{*}$ NOTE: Liberty Link cotton use is limited to the area north of Tampa (Florida Route 60). Also, Liberty will kill Roundup Ready cotton, and vice versa.

\section{ROTATION RESTRICTIONS}

Liberty requires a 120-day restriction for all rotational crops, except for wheat, barley, sorghum, and other crops listed on the label.

\section{Roundup Ready Cotton}

Roundup Ready cotton has been genetically modified to tolerate glyphosate. There are several products containing glyphosate, but all are not labeled for use on Roundup Ready cotton. Consult your local UF/IFAS Extension agent or the labels; use only those glyphosate products that are labeled for use on Roundup Ready cotton. Glyphosate provides control of broadleaf weeds, grasses, and nutsedges. Proper application timing must be used to avoid crop injury.

\section{APPLICATION TIMING}

Proper glyphosate application timing is essential to avoid injury in Roundup Ready cotton. Glyphosate can be applied over the top of Roundup Ready cotton anytime from cotton emergence until the fourth true-leaf stage. Applications of glyphosate over the top of cotton are prohibited after the cotton exceeds the four-leaf stage, except in salvage situations. These late (after four-leaf) over-top applications 
will result in bloom abortion and loss of yield. For Roundup Ready Flex cotton, glyphosate can be applied from cotton emergence until 7 days prior to harvest.

Roundup can be applied post-directed until layby. Consult the label for the suggested use rate. Glyphosate can be applied twice over the top of Roundup Ready cotton when the following criteria are met. The two applications must be at least 10 days apart. There must be two nodes of new growth between the applications. Lastly, the second application must be made before cotton exceeds the four-leaf stage. Therefore, if you are going to use two over-the-top applications, you must make the first application prior to the second true leaf, and the second application during the fourth true leaf stage.

Directed glyphosate applications must have minimal contact with the cotton plant when applied after the four-leaf stage. Glyphosate can be applied late-season after $20 \%$ of the bolls have cracked. At least 7 days between application and harvest are necessary.

\section{HERBICIDE PROGRAM}

Preemergence-An advantage to the Roundup Ready system is the option to eliminate preemergence herbicides. Early-season weed competition should be considered when determining the weed management program. This competition may be avoided by an early glyphosate application (i.e., one-leaf stage). If a preemergence herbicide is used, the glyphosate application can be delayed until the three- or four-leaf stage. Consideration should be given to total cotton acreage, weed spectrum, and acceptable risk level when weather delays postemergence applications. Preemergence herbicides are a type of insurance policy and often maintain a grower's peace of mind. A soil-applied preemergence herbicide should be utilized in the program to provide early-season control of annual grasses and Florida pusley (Table 3).

\section{TANK MIXES}

Glyphosate does not provide any soil or residual activity. Therefore, tank mixtures can be utilized for broad-spectrum weed control and/or residual activity. A tank mix of Staple and glyphosate improves control of hemp sesbania, spreading dayflower, and morning glory species (all except tall). A premix of this combination is available under the trade name Staple Plus.

Tables 4, 5, and 6 can be helpful in choosing the herbicide that is best suited for your particular situation.

\section{XtendFlex Cotton}

XtendFlex cotton has been genetically modified to tolerate dicamba herbicide. There are several dicamba products, but only newer, low-volatility dicamba-containing products (XtendiMax, Engenia, Fexapan) are labeled for XtendFlex cotton. Other dicamba products (Clarity, Banvel, etc.) are not labeled for use in XtendFlex cotton. Consult your county's UF/IFAS Extension agent and read and follow label instructions carefully to use the appropriate dicamba product in the XtendFlex system. There are several requirements to consider for dicamba application in XtendFlex cotton. These requirements include completion of dicamba training, proper spray record keeping, downwind buffer, application rate, application time, wind speed, nozzles, spray volume, tank-mix partners, spray adjuvants, ground speed, boom height, and spray equipment clean-out. Dicamba herbicide is effective only on broadleaf weed species (less than 4 inches tall) and does not provide control of grass weeds.

\section{APPLICATION TIMING}

Dicamba herbicide products' application window is no later than 60 days after planting or mid-bloom, whichever comes first. Apply dicamba herbicide products at a wind speed between 3 to $10 \mathrm{mph}$ and a minimum of 15 gallons per acre (GPA). Do not exceed a boom height of 24 inches, and do not exceed a ground speed of $15 \mathrm{mph}$. Do not use ammonium sulfate as a water conditioning adjuvant. Apply one hour after sunrise until two hours before sunset. Do not apply during temperature inversion conditions (e.g., when visible dew and low-lying fog are present in the field). Do not aerially apply Enlist herbicide products.

\section{Enlist Cotton}

Enlist cotton has been genetically modified to tolerate 2,4-D herbicide. Only 2,4-D choline herbicide-containing products (Enlist Duo and Enlist One) are labeled for Enlist cotton. Other 2,4-D products (2,4-D Amine, 2,4-D Ester, LV4, etc.) are not labeled for use in Enlist cotton. Consult your county's UF/IFAS Extension agent and read and follow label instructions carefully for appropriate 2,4-D products in Enlist cotton. There are several requirements to consider for 2,4-D application in Enlist cotton. These include application timing/window, tank-mix partners, nozzles, sprayer contamination, wind speed, environmental condition, buffer area, spray volume, spray pressure, herbicide rate, boom height, and spray equipment clean-out. 2,4-D herbicide alone is effective only on broadleaf weed species (less than 4 inches tall) and does not provide control of grass weeds. 


\section{APPLICATION TIMING}

Enlist herbicides' application window is after cotton emergence but no later than full flowering or mid-bloom stage. Wind speed between 3 and $10 \mathrm{mph}$ and spray volume of 10-15 GPA are most desirable for Enlist herbicide application. Do not apply at a wind speed greater than $15 \mathrm{mph}$. Do not apply during conditions of temperature inversion (inversions are more frequent between dusk and dawn). Do not aerially apply Enlist herbicide products.

Tables 4, 5, and 6 can help you choose the most suitable herbicide for your particular situation. 
Table 1. Weed management in non-transgenic cotton.

\begin{tabular}{|c|c|c|}
\hline $\begin{array}{l}\text { Trade Name and Broadcast } \\
\text { Rate/Acre of Commercial } \\
\text { Product }\end{array}$ & $\begin{array}{l}\text { Common Name and } \\
\text { Broadcast Rate/Acre of } \\
\text { Active Ingredient }\end{array}$ & Remarks \\
\hline \multicolumn{3}{|r|}{ BURNDOWN HERBICIDES } \\
\hline Glyphosate (several) & $\begin{array}{l}\text { glyphosate } \\
(0.5-1.0 \mathrm{lb})\end{array}$ & $\begin{array}{l}\text { Use higher rate for larger weeds or heavy infestations. Use a } 0.25 \% \text { v/v surfactant } \\
\text { with some formulations. Apply after weed emergence up to } 3-7 \text { days before } \\
\text { planting. Touchdown must be applied at least } 35 \text { days before planting. If tillage } \\
\text { is intended after treatment, wait at least } 3 \text { days. Rainfall within } 6 \text { hours after } \\
\text { application may decrease control. }\end{array}$ \\
\hline $\begin{array}{l}\text { glyphosate } \\
\text { (several) } \\
+ \\
2,4-\mathrm{D} \\
(0.5-1 \mathrm{pt})\end{array}$ & $\begin{array}{l}\text { glyphosate } \\
+ \\
2,4-D\end{array}$ & $\begin{array}{l}\text { The addition of 2,4-D will increase control of cutleaf evening primrose, wild radish, } \\
\text { horseweed, and other winter annuals. Cotton planting must be delayed for a } \\
\text { minimum of } 30 \text { days after 2,4-D application. }\end{array}$ \\
\hline $\begin{array}{l}\text { glyphosate } \\
\text { (several) } \\
+ \\
\text { Clarity } \\
\text { (8 fl oz) }\end{array}$ & $\begin{array}{l}\text { glyphosate } \\
(0.5-1 \mathrm{lb}) \\
+ \\
\text { dicamba }\end{array}$ & $\begin{array}{l}\text { Following application of dicamba AND a minimum of } 1 \text { in of rainfall, a waiting } \\
\text { period of at least } 21 \text { days is required before planting. Dicamba can be applied } \\
\text { alone with little to no effect on the small grain cover crop. } \\
\text { Dicamba is less effective than 2,4-D on primrose. }\end{array}$ \\
\hline \multicolumn{3}{|l|}{$\begin{array}{l}\text { Harmony Extra } 50 \text { SG } \\
0.75 \mathrm{oz} / \mathrm{A} \\
\text { or } \\
\text { Harmony Extra } 75 \text { WDG } \\
0.5 \mathrm{oz} / \mathrm{A}\end{array}$} \\
\hline $\begin{array}{l}\text { glyphosate } \\
\text { (several) } \\
+ \\
\text { Valor } \\
(1-2 \text { oz) }\end{array}$ & $\begin{array}{l}\text { glyphosate } \\
\qquad+ \\
\text { flumioxazin }\end{array}$ & $\begin{array}{l}\text { The addition of Valor will increase control of cutleaf evening primrose and wild } \\
\text { radish. A minimum of } 14 \text { days must pass and } 1 \text { in of water must accumulate before } \\
\text { planting cotton if } 1 \text { oz of Valor is used. If using } 2 \text { oz, delay planting for } 21 \text { days. } \\
\text { Valor will give approximately } 6 \text { weeks of residual control of small-seeded weeds } \\
\text { (pigweeds, Florida pusley, smallflower morning glory) if adequate soil contact } \\
\text { occurs. For resistance management, do not use Reflex preplant or Valor at layby if } \\
\text { Valor is applied at burndown. }\end{array}$ \\
\hline $\begin{array}{l}\text { Gramoxone } S L \\
\quad(2.5-4 \mathrm{pt}) \\
\text { Firestorm, Parazone, others } \\
(1.7-2.7 \mathrm{pt})\end{array}$ & paraquat & $\begin{array}{l}\text { Apply prior to, during, or after planting but before crop emergence. Should be } \\
\text { applied in at least } 10 \text { gal spray solution per acre. May be mixed with 2,4-D to } \\
\text { improve activity on some broadleaf weeds. See information below for specifics on } \\
\text { 2,4-D. }\end{array}$ \\
\hline $\begin{array}{l}\text { Paraquat (several) } \\
+ \\
\text { Direx } 4 \mathrm{~L} \\
(1.6 \mathrm{pt})\end{array}$ & $\begin{array}{l}\text { paraquat } \\
\quad+ \\
\text { diuron }\end{array}$ & $\begin{array}{l}\text { Do not apply on sand or loamy sand soil. Higher rates of diuron may be used on } \\
\text { heavier soils; see labels. Apply diuron } 15-45 \text { days ahead of planting. If Cotoran is } \\
\text { applied preemergence, reduce rate to account for residual activity of diuron. }\end{array}$ \\
\hline $\begin{array}{l}2,4-D \text { ester or amine } \\
\text { (various formulations) }\end{array}$ & $\begin{array}{c}2,4-D \\
(0.37-1.0 \mathrm{lb})\end{array}$ & $\begin{array}{l}\text { The most consistent and effective burndown program for winter weeds in Florida } \\
\text { would be a } 2,4-D \text { application in February when weeds are small and herbicide } \\
\text { coverage is adequate followed by glyphosate or paraquat at or near planting. } \\
\text { Primrose: Apply } 0.37-0.5 \mathrm{lb} \text { ai/A. } \\
\text { Radish: Apply } 0.5-0.75 \mathrm{lb} \text { ai/A. } \\
\text { Horseweed: Apply } 0.75-1.0 \mathrm{lb} \text { ai/A. } \\
\text { Plant-back restriction for } 2,4-\mathrm{D} \text { is often } 30 \text { days. See the specific product label to } \\
\text { determine the cotton plant-back interval. }\end{array}$ \\
\hline \multicolumn{3}{|r|}{ PREPLANT } \\
\hline $\begin{array}{l}\text { Treflan/various } \\
\text { (1-2 pt) } \\
\text { or } \\
\text { Pendimethalin } 3.3 \mathrm{EC} \\
\quad(1.2-1.8 \mathrm{pt}) \\
\text { or } \\
\text { Prowl } \mathrm{H}_{2} \mathrm{O} 3.8 \mathrm{AS} \\
(2 \mathrm{pt})\end{array}$ & $\begin{array}{c}\text { trifluralin } \\
\text { pendimethalin }\end{array}$ & $\begin{array}{l}\text { Good control of annual grasses and certain broadleaf weeds. Poor control of } \\
\text { cocklebur, sicklepod (coffeeweed), morning glory, and ragweed. No nutsedge } \\
\text { control. Incorporate thoroughly according to label directions. The spectrum } \\
\text { of weeds controlled is similar for each of these herbicides. Treflan must be } \\
\text { incorporated with tillage or irrigation within } 24 \text { hours of application. Prowl } \mathrm{H}_{2} \mathrm{O} \text { will } \\
\text { persist on the soil surface much longer than Prowl } 3.3 \mathrm{EC} \text { or Treflan. }\end{array}$ \\
\hline
\end{tabular}




\begin{tabular}{|c|c|c|}
\hline $\begin{array}{l}\text { Trade Name and Broadcast } \\
\text { Rate/Acre of Commercial } \\
\text { Product }\end{array}$ & $\begin{array}{l}\text { Common Name and } \\
\text { Broadcast Rate/Acre of } \\
\text { Active Ingredient }\end{array}$ & Remarks \\
\hline $\begin{array}{l}\text { Solicam } \\
(1.25 \mathrm{lb})\end{array}$ & norflurazon & $\begin{array}{l}\text { May be applied tank-mixed with Treflan or Prowl and can give good to excellent } \\
\text { control of prickly sida with enhanced control of deep germinating weeds such } \\
\text { as cocklebur or morning glory. If dry conditions predominate, control may be } \\
\text { superior to PRE applications when applied PPI. If used PPI, do not exceed } 2.5 \mathrm{lb} \text { of } \\
\text { Solicam total per season in both PPI and PRE applications. See label for rotation } \\
\text { restrictions. }\end{array}$ \\
\hline \multicolumn{3}{|r|}{ PREEMERGENCE } \\
\hline $\begin{array}{l}\text { Cotoran } 4 \mathrm{~L} \text { or Flo-Met } 4 \mathrm{~L} \\
\qquad(2.0-3.2 \mathrm{pt})\end{array}$ & fluometuron & $\begin{array}{l}\text { Apply after planting and before emergence of the crop or weeds. Good control of } \\
\text { annual grass and broadleaf weeds. Use low rate on sandy soils. }\end{array}$ \\
\hline $\begin{array}{c}\text { Direx DF } \\
(1.0-1.5 \mathrm{lb}) \\
\text { or } \\
\text { Direx 4L } \\
(1.6-2.4 \mathrm{pt})\end{array}$ & diuron & Similar to fluometuron but less effective on large-seeded broadleaf weeds. \\
\hline $\begin{array}{l}\text { Reflex } 2 \mathrm{~L} \\
1 \mathrm{pt} / \mathrm{A}\end{array}$ & fomesafen & $\begin{array}{l}\text { Particularly useful for fields infested with glyphosate-resistant Palmer amaranth. } \\
\text { Can injure cotton if soils have low organic matter content or if heavy rainfall occurs } \\
\text { during cotton emergence. For resistance management, make only one application } \\
\text { of Reflex or Valor per crop per year. }\end{array}$ \\
\hline $\begin{array}{l}\text { Solicam } \\
(1.25-2.5 \mathrm{lb})\end{array}$ & norflurazon & $\begin{array}{l}\text { Apply after planting and before emergence of crop or weeds. Good control of } \\
\text { annual grasses and many broadleaf weeds. May suppress nutsedge. May cause } \\
\text { problems with rotational crops such as cereal grains and corn. Consult label for } \\
\text { specific restrictions. Solicam will not adequately control Palmer amaranth. }\end{array}$ \\
\hline $\begin{array}{l}\text { Staple LX } \\
1.7-2.1 \mathrm{oz}\end{array}$ & pyrithiobac & $\begin{array}{l}\text { Do not apply on soils with less than } 0.5 \% \text { organic matter. Can tank-mix with } \\
\text { Diuron, Cotoran, or Prowl. Palmer amaranth biotypes resistant to Staple are } \\
\text { present in Florida. }\end{array}$ \\
\hline \multicolumn{3}{|r|}{ POSTEMERGENCE } \\
\hline $\begin{array}{l}\text { Dual Magnum } \\
\quad(1-1.33 \mathrm{pt})\end{array}$ & S-metolachlor & $\begin{array}{l}\text { DO NOT APPLY PREEMERGENCE OR SEVERE COTTON INJURY WILL OCCUR. To } \\
\text { control tropical spiderwort, apply at the four-leaf stage of cotton. Dual will only } \\
\text { control weeds that have NOT emerged. To increase effectiveness, efforts should be } \\
\text { made to maximize soil contact by spray solution. Metolachlor-containing products } \\
\text { will often result in slight cotton leaf damage, especially if applied in hot, humid } \\
\text { conditions or when dew covers the leaf. This injury will persist approximately } 7 \\
\text { days, but yield will not be affected. Cinch and Dual Il Magnum are not registered } \\
\text { for use in cotton. }\end{array}$ \\
\hline $\begin{array}{l}\text { Envoke } \\
(0.1 \mathrm{oz})\end{array}$ & trifloxysulfuron & $\begin{array}{l}\text { Excellent control of sicklepod, morning glory (except smallflower morning glory), } \\
\text { and nutsedges. Apply with nonionic surfactant }(0.25 \% \mathrm{v} / \mathrm{v}) \text { from the cotton five- } \\
\text { leaf stage until } 60 \text { days before harvest. DO NOT apply prior to five-leaf stage or } \\
\text { unacceptable cotton injury will result. Do not tank-mix with other herbicides, oil } \\
\text { adjuvants, fertilizers, or insecticides. Do not apply over the top of stripper-type } \\
\text { cottons. Do not apply more than } 0.4 \text { oz/A/yr. }\end{array}$ \\
\hline $\begin{array}{l}\text { Fusilade DX } \\
(6-12 \mathrm{oz})\end{array}$ & fluazifop-butyl & $\begin{array}{l}\text { Apply for control of most annual and perennial grasses before they reach a height } \\
\text { greater than } 4 \text { in. See label for specific rates and weeds. Add crop oil concentrate } \\
\text { (1 gal) or nonionic surfactant ( } 2 \text { pt) per } 100 \text { gal spray mixture. }\end{array}$ \\
\hline $\begin{array}{c}\text { Poast } \\
(0.75-2.5 \mathrm{pt}) \\
\text { or } \\
\text { Poast Plus } \\
(1.0-3.75 \mathrm{pt})\end{array}$ & sethoxydim & $\begin{array}{l}\text { Apply for control of most annual and perennial grasses, before grass height } \\
\text { exceeds } 4 \text { in. Include a crop oil concentrate at } 2 \text { pt/A. Herbicide applications must } \\
\text { be made no later than } 40 \text { days before harvest. }\end{array}$ \\
\hline $\begin{array}{l}\text { Select, Arrow, Shadow, others } \\
\qquad(6-16 \mathrm{oz})\end{array}$ & clethodim & $\begin{array}{l}\text { Apply for the control of annual and perennial grasses. For annual grasses up to } \\
6 \text { in tall, apply } 6 \text { oz/A. A second application may be made. Higher rates will be } \\
\text { necessary for rhizome johnsongrass, bermudagrass, and other perennial grasses. } \\
\text { Add crop oil concentrate at } 1 \text { gal per } 100 \text { gal of spray mixture. }\end{array}$ \\
\hline $\begin{array}{l}\text { Select Max or TapOut } \\
\quad(12-32 \mathrm{oz})\end{array}$ & clethodim & $\begin{array}{l}\text { Control will be similar to that of Select, Arrow, or Trigger. Select Max can be applied } \\
\text { with either a crop oil or nonionic surfactant. }\end{array}$ \\
\hline
\end{tabular}




\begin{tabular}{|c|c|c|}
\hline $\begin{array}{l}\text { Trade Name and Broadcast } \\
\text { Rate/Acre of Commercial } \\
\text { Product }\end{array}$ & $\begin{array}{l}\text { Common Name and } \\
\text { Broadcast Rate/Acre of } \\
\text { Active Ingredient }\end{array}$ & Remarks \\
\hline $\begin{array}{l}\text { Staple LX } \\
(2.6-3.8 \mathrm{oz})\end{array}$ & pyrithiobac & $\begin{array}{l}\text { Apply over the top of cotton from cotyledonary stage up to } 60 \text { days prior to } \\
\text { harvest. Avoid applying shortly before or after cool weather. Include nonionic } \\
\text { surfactant at } 0.25 \% \text { by volume ( } 1 \text { qt per } 100 \text { gal spray mix). Do not add crop oil. } \\
\text { May make two applications per year, not exceeding a total of } 5.1 \text { fl oz. May mix } \\
\text { with } 1 \mathrm{pt} / \mathrm{A} \text { of MSMA when cotton is } 3-6 \text { in to improve sicklepod control; however, } \\
\text { this mixture may reduce pigweed control by Staple. } \\
\text { Do not mix with grass control herbicides. May tank-mix with most insecticides, } \\
\text { but do not tank-mix with any product containing malathion. Do not mix with any } \\
\text { Dual product. Separate Staple and Dual applications by } 5 \text { or more days. See label } \\
\text { for rotational restrictions. }\end{array}$ \\
\hline \multicolumn{3}{|r|}{ DIRECTED POSTEMERGENCE } \\
\hline $\begin{array}{l}\operatorname{Aim} 2 \mathrm{EC} \\
0.8-1.6 \mathrm{oz}\end{array}$ & carfentrazone & $\begin{array}{l}\text { Apply as a directed spray after cotton has reached a height of } 12 \text { in with sufficient } \\
\text { bark development. Direct spray below foliage or leaf burning will occur. For best } \\
\text { activity, weed height should be less than } 4 \text { in. See herbicide label for specific rate } \\
\text { information. Applications should be made with crop oil concentrate at } 1 \% \mathrm{v} / \mathrm{v} \text {. }\end{array}$ \\
\hline $\begin{array}{c}\text { Cotoran } 4 \mathrm{~L} \text { or Meturon } 4 \mathrm{~L} \\
(2.4 \mathrm{pt}) \\
\text { or } \\
\text { Cotoran DF or Meturon DF } \\
(1.5 \mathrm{lb}) \\
+ \\
\text { MSMA } \\
\text { (several formulations) }\end{array}$ & $\begin{array}{l}\text { fluometuron } \\
+ \\
\text { MSMA }\end{array}$ & $\begin{array}{l}\text { Apply as a directed spray after cotton is } 3-4 \text { in tall. Add a surfactant if not included } \\
\text { in MSMA formulation. Controls a broad spectrum of weeds. Do not apply over the } \\
\text { top of cotton. Do not apply after cotton begins blooming. }\end{array}$ \\
\hline $\begin{array}{l}\text { Caparol 4L } \\
(1.3-2.4 \mathrm{pt}) \\
+ \\
\text { MSMA } \\
(2.5 \mathrm{pt})\end{array}$ & $\begin{array}{l}\text { prometryn } \\
+ \\
\text { MSMA }\end{array}$ & $\begin{array}{l}\text { Apply this tank mixture as a directed spray after cotton is } 6 \text { in tall. Add a surfactant } \\
\text { if not included in MSMA formulation. Broad-spectrum weed control. Do not apply } \\
\text { over the top of cotton. Do not apply after cotton is blooming. }\end{array}$ \\
\hline $\begin{array}{l}\text { Direx 4F } \\
(0.8-2.4 \mathrm{pt}) \\
+ \\
\text { MSMA } \\
(2.5 \mathrm{pt})\end{array}$ & $\begin{array}{l}\text { diuron } \\
+ \\
\text { MSMA }\end{array}$ & $\begin{array}{l}\text { Apply in cotton higher than } 12 \text { in for grass, broadleaf, and sedge control. Higher } \\
\text { diuron rates will provide increased soil residual activity. For control of large } \\
\text { morning glory, Aim } 2 \mathrm{EC} \text { may be added. If including Aim, delay application until } \\
\text { cotton reaches a height of } 16 \mathrm{in} \text {. }\end{array}$ \\
\hline $\begin{array}{c}\text { ET } \\
(0.5-1 \mathrm{oz})\end{array}$ & pyraflufen-ethyl & $\begin{array}{l}\text { Apply after cotton reaches } 18 \text { in with } 3 \text { in of basal bark. Weeds should be } 6 \text { in or } \\
\text { less at time of application. Avoid spray contact with desirable foliage. Do not apply } \\
\text { more than } 1 \text { oz per season. Glyphosate or MSMA may be added to improve grass } \\
\text { or nutsedge activity. Information on the full weed spectrum controlled by this } \\
\text { herbicide is currently limited. }\end{array}$ \\
\hline $\begin{array}{l}\text { Goal } 2 X L \\
(1.0-2.0 \mathrm{pt})\end{array}$ & oxyfluorfen & $\begin{array}{l}\text { Apply as a directed spray to weeds less than } 4 \text { in tall and after cotton is } 8 \text { in tall. } \\
\text { Sprayed cotton foliage will be injured. }\end{array}$ \\
\hline $\begin{array}{c}\text { Cobra } \\
(13 \mathrm{oz}) \\
+ \\
\text { MSMA } \\
\text { (several formulations) }\end{array}$ & $\begin{array}{l}\text { lactofen } \\
+ \\
\text { MSMA }\end{array}$ & $\begin{array}{l}\text { Apply as a directed spray to weeds } 4 \text { in tall and after cotton is } 8 \text { in tall (preferably } \\
12 \text { in tall), and broadleaf weeds are } 3-5 \text { in smaller than the lowest cotton leaves. } \\
\text { Cotton foliage sprayed will be injured. Add a crop oil if stem bark is present; use } \\
\text { nonionic surfactant prior to bark formation. The use of crop oil will cause more } \\
\text { cotton injury if the spray contacts green stem tissue. }\end{array}$ \\
\hline $\begin{array}{c}\text { Layby Pro } \\
(2 \mathrm{pt}) \\
+ \\
\text { MSMA } \\
(2.5 \mathrm{pt})\end{array}$ & $\begin{array}{c}\text { diuron + linuron } \\
+ \\
\text { MSMA }\end{array}$ & Apply as directed spray in cotton that is at least 16 in tall until first bloom. \\
\hline $\begin{array}{l}\text { Linex } \\
(1-3 p t)\end{array}$ & linuron & $\begin{array}{l}\text { Apply } 1 \text { pt at } 6 \text {-in cotton followed by } 1.5 \text { pt at 8-in cotton. Alternatively, cotton } \\
\text { reaching } 20 \text { in may receive } 2 \text { or } 3 \text { pt. Use a nonionic surfactant at } 1 \text { pt per } 25 \text { gal. } \\
\text { Weed control will be similar to that of Diuron. }\end{array}$ \\
\hline
\end{tabular}




\begin{tabular}{|c|c|c|}
\hline $\begin{array}{l}\text { Trade Name and Broadcast } \\
\text { Rate/Acre of Commercial } \\
\text { Product }\end{array}$ & $\begin{array}{l}\text { Common Name and } \\
\text { Broadcast Rate/Acre of } \\
\text { Active Ingredient }\end{array}$ & Remarks \\
\hline $\begin{array}{l}\text { Prowl } 3.3 \mathrm{EC} \\
(1.8-2.4 \mathrm{pt}) \\
\text { or } \\
\text { Prowl } \mathrm{H}_{2} 0 \\
\quad(2 \mathrm{pt})\end{array}$ & pendimethalin & $\begin{array}{l}\text { Do NOT spray over the top of cotton. Apply as a directed layby spray to cotton. } \\
\text { Does NOT control emerged weeds. Apply after controlling existing weeds. } \\
\text { Alternatively, pendimethalin may be tank-mixed with any registered layby } \\
\text { herbicide, including glyphosate in Roundup Ready cotton. With adequate rainfall } \\
\text { or irrigation for activation, pendimethalin will provide residual control of annual } \\
\text { grasses and pigweed species. Avoid contact of spray with the non-woody portion } \\
\text { of cotton stems and cotton foliage or serious crop injury may result. Apply at least } \\
60 \text { days prior to harvest. }\end{array}$ \\
\hline $\begin{array}{l}\text { Suprend } \\
(1.0-1.5 \mathrm{lb})\end{array}$ & $\begin{array}{l}\text { trifloxysulfuron-sodium } \\
+ \\
\text { prometryn }\end{array}$ & $\begin{array}{l}\text { For excellent control of morning glories, pigweeds, sicklepod, and sedges. Do not } \\
\text { apply more than } 2.7 \mathrm{lb} / \mathrm{A} / \mathrm{yr} \text {. Sequential applications can be made after } 14 \text { days. Do } \\
\text { not apply within } 60 \text { days of harvest. }\end{array}$ \\
\hline $\begin{array}{c}\text { Valor } \\
(1-2 \mathrm{oz})\end{array}$ & flumioxazin & $\begin{array}{l}\text { For excellent control of morning glory and numerous other broadleaf weeds. } \\
\text { For improved grass control, glyphosate should be added. Add MSMA to improve } \\
\text { sedge and Palmer amaranth control. Applications should be made when cotton } \\
\text { has reached a height of } 16 \text { in and spray should be directed to the bottom } 2 \text { in of } \\
\text { the stem. A nonionic surfactant should be added to the spray mixture at } 0.25 \% \\
\text { v/v. DO NOT apply Valor with crop oil or any other spray additive except nonionic } \\
\text { surfactants. The manufacturer recommends that a separate sprayer be dedicated } \\
\text { to Valor since clean-out is difficult and Valor is extremely injurious to plant foliage. } \\
\text { For resistance management, only use Reflex or Valor once per cropping season. }\end{array}$ \\
\hline \multicolumn{3}{|r|}{ HOODED APPLICATIONS } \\
\hline $\begin{array}{c}\text { ET } \\
1-2 \mathrm{oz}\end{array}$ & pyraflufen-ethyl & $\begin{array}{l}\text { Hooded applications are required for cotton with less than } 3 \text { in of stem bark. Do } \\
\text { not exceed } 2 \text { oz/A/yr with this use. Spray that escapes the hood will result in crop } \\
\text { injury. ET can be mixed with glyphosate or other herbicides. }\end{array}$ \\
\hline Several & $\begin{array}{l}\text { glyphosate } \\
(0.56-0.75 \mathrm{lb})\end{array}$ & $\begin{array}{l}\text { Controls annual and perennial grasses and broadleaf weeds. In non-Roundup } \\
\text { Ready cotton, keep hoods in contact with the ground and avoid contact with } \\
\text { foliage or stems. Do not exceed } 5 \mathrm{mph} \text {. Allow } 7 \text { days between application and } \\
\text { harvest. To control large morning glory plants, Aim, Caparol, Direx, or Harvade may } \\
\text { be mixed with certain glyphosate formulations. }\end{array}$ \\
\hline $\begin{array}{l}\text { Gramoxone } 2 \text { SL } \\
\quad(19-38 \mathrm{oz})\end{array}$ & paraquat & $\begin{array}{l}\text { DO NOT CONTACT COTTON STEMS OR FOLIAGE. Apply in a minimum of } 10 \text { GPA at } \\
\text { a maximum of } 25 \text { PSI. Do not exceed } 5 \text { mph. Hoods should be kept as close to the } \\
\text { ground as possible. Cotton should be at least } 8 \text { in tall. Add nonionic surfactant or } \\
\text { crop oil concentrate according to the label. Caparol or diuron (Direx) may be mixed } \\
\text { with paraquat. Tank mixes are usually more effective. }\end{array}$ \\
\hline
\end{tabular}

Table 2. Herbicide program for Liberty Link cotton.

\begin{tabular}{|c|c|c|}
\hline $\begin{array}{c}\text { Trade Name and } \\
\text { Broadcast Rate/Acre of } \\
\text { Commercial Product }\end{array}$ & Common Name & Remarks \\
\hline $\begin{array}{l}\text { Liberty } 280 \\
(23-43 \text { oz) }\end{array}$ & glufosinate & $\begin{array}{l}\text { Apply to Liberty Link varieties only. May be applied from cotton emergence to early bloom. } \\
\text { Provides excellent control of morning glory, cocklebur, and ragweed, but is less effective } \\
\text { on perennial weeds and grasses. Adequate spray coverage is essential for weed control. Do } \\
\text { not apply more than } 40 \text { oz/ac per application or } 80 \mathrm{oz} / \mathrm{ac} / \mathrm{year} \text {. Not for use south of Tampa, } \\
\text { FL (Route } 60 \text { ). Addition of ammonium sulfate ( } 3 \mathrm{lb} / \mathrm{ac} \text { ) often improves weed control. NOTE: } \\
\text { ROUNDUP READY COTTON WILL NOT TOLERATE LIBERTY } 280 \text { APPLICATIONS. }\end{array}$ \\
\hline $\begin{array}{l}\text { Liberty } 280 \\
\quad(23-29 \text { oz) } \\
\quad+ \\
\text { Dual Magnum } \\
(1-1.33 \text { pt })\end{array}$ & $\begin{array}{c}\text { glufosinate } \\
+ \\
\text { S-metolachlor }\end{array}$ & $\begin{array}{l}\text { Apply to Liberty Link varieties only. Do not apply Dual Magnum preemergence or } \\
\text { severe injury will occur. Dual Magnum will provide residual control of grasses (except Texas } \\
\text { panicum) and certain broadleaf weeds. Dual Magnum will only control weeds that have not } \\
\text { emerged. Dual Magnum will provide good control of tropical spiderwort. Leaf burning may } \\
\text { occur after application. }\end{array}$ \\
\hline $\begin{array}{l}\text { Liberty } 280 \\
(23-29 \text { oz }) \\
\quad+ \\
\text { Staple } \\
(1.3-1.9 \text { oz) }\end{array}$ & $\begin{array}{c}\text { glufosinate } \\
+ \\
\text { pyrithiobac }\end{array}$ & $\begin{array}{l}\text { Apply to Liberty Link varieties only. Staple provides additional broadleaf control } \\
\text { (particularly of pigweeds) as well as residual soil activity. }\end{array}$ \\
\hline
\end{tabular}


Table 3. Herbicide program for Roundup Ready cotton.

\begin{tabular}{|c|c|c|}
\hline $\begin{array}{c}\text { Trade Name and } \\
\text { Broadcast Rate/Acre of } \\
\text { Commercial Product }\end{array}$ & $\begin{array}{c}\text { Common Name and } \\
\text { Broadcast Rate/Acre of } \\
\text { Active Ingredient }\end{array}$ & Remarks \\
\hline Glyphosate (several) & $\begin{array}{l}\text { glyphosate } \\
(0.5-1.0 \mathrm{lb})\end{array}$ & $\begin{array}{l}\text { Apply to Roundup Ready varieties only. Avoid drift to non-Roundup Ready cotton } \\
\text { and other sensitive crops. Apply in 5-20 gal of spray per acre over the top from crop } \\
\text { emergence through four-leaf stage. Directed application is required if cotton has more } \\
\text { than four leaves. May be applied over the top twice up to the fourth true-leaf stage, } \\
\text { unless Roundup Ready Flex cotton is used. Separate sequential applications by at least } \\
10 \text { days and two nodes of new growth. Different glyphosate brands contain differing } \\
\text { amounts of active ingredient surfactant requirements. Read specific product labels } \\
\text { prior to product use. }\end{array}$ \\
\hline $\begin{array}{c}\text { Glyphosate } \\
\text { (several) } \\
+ \\
\text { Dual Magnum (and } \\
\text { others) } \\
(1.33 \mathrm{pt}) \\
\text { or } \\
\text { Sequence } \\
\text { (2.5 pt) }\end{array}$ & $\begin{array}{l}\text { glyphosate } \\
\quad \begin{array}{l}(0.75 \mathrm{lb}) \\
\quad+ \\
\text { S-metolachlor } \\
\quad(1.25 \mathrm{lb})\end{array}\end{array}$ & $\begin{array}{l}\text { Apply to Roundup Ready varieties only. Do not apply Dual Magnum } \\
\text { preemergence or severe injury will occur. Dual Magnum will provide residual control } \\
\text { of grasses (except Texas panicum) and certain broadleaf weeds. Dual Magnum will } \\
\text { only control weeds that have not emerged. Dual Magnum will provide good control of } \\
\text { tropical spiderwort. Leaf burning may occur after application. }\end{array}$ \\
\hline $\begin{array}{l}\text { Glyphosate } \\
\text { (several) } \\
\quad+ \\
\text { Staple LX } \\
(1.3-3.8 \text { oz) }\end{array}$ & $\begin{array}{c}\text { glyphosate } \\
(0.75 \mathrm{lb}) \\
+ \\
\text { pyrithiobac }\end{array}$ & $\begin{array}{l}\text { Apply to Roundup Ready varieties only. See above comments. Apply over the top } \\
\text { from one to four true leaves. Do not apply over the top after cotton exceeds four-leaf } \\
\text { stage unless it is Roundup Ready Flex. Staple LX provides additional broadleaf control } \\
\text { as well as residual soil activity. } \\
\text { Do not apply during periods of cool, wet weather. Occasional injury has been } \\
\text { associated with this mixture. Injury is worse when applications are made in high- } \\
\text { humidity or dewy conditions. }\end{array}$ \\
\hline $\begin{array}{c}\text { Glyphosate } \\
+ \\
\text { Valor } \\
(1-2 \text { oz })\end{array}$ & $\begin{array}{c}\text { glyphosate } \\
(0.75 \mathrm{lb}) \\
+ \\
\text { flumioxazin }\end{array}$ & $\begin{array}{l}\text { Apply as a directed spray. Cotton must be } 16 \text { in tall. Do not mix with crop oil. Direct } \\
\text { spray to the bottom } 2 \text { in of the stem. Valor provides excellent control of morning glory } \\
\text { and significant soil residual activity. Applications of } 1 \text { oz per acre are generally sufficient } \\
\text { to control weeds. } \\
\text { For resistance management, do not use Reflex or Valor more than once per season. }\end{array}$ \\
\hline $\begin{array}{c}\text { Glyphosate } \\
+ \\
\text { Caparol } \\
(1-2 \mathrm{pt})\end{array}$ & $\begin{array}{c}\text { glyphosate } \\
(0.75 \mathrm{lb}) \\
+ \\
\text { prometryn }\end{array}$ & $\begin{array}{l}\text { Apply as a directed spray. Cotton should be at least } 8 \text { in tall for } 1 \text { pt of Caparol and } 12 \text { in } \\
\text { tall for rates higher than } 1 \text { pt. }\end{array}$ \\
\hline $\begin{array}{c}\text { Glyphosate } \\
+ \\
\text { Aim 2EC } \\
(0.8-1.6 \mathrm{oz})\end{array}$ & $\begin{array}{c}\text { glyphosate } \\
(0.75 \mathrm{lb}) \\
+ \\
\text { carfentrazone }\end{array}$ & $\begin{array}{l}\text { Apply as a directed spray. Cotton must be } 16 \text { in tall. Aim provides excellent control of } \\
\text { large morning glory. Aim can also cause severe cotton injury if the application is not } \\
\text { precisely made. See Aim label for precautions. }\end{array}$ \\
\hline $\begin{array}{l}\text { Glyphosate } \\
\text { (several) } \\
\quad+ \\
\text { Direx 4F } \\
(1-1.5 \mathrm{pt})\end{array}$ & $\begin{array}{l}\text { glyphosate } \\
(0.75 \mathrm{lb}) \\
+ \\
\text { diuron }\end{array}$ & $\begin{array}{l}\text { APPLY POST-DIRECTED TO ROUNDUP READY CULTIVARS ONLY. Use } 1 \text { pt of Direx on } \\
\text { cotton } 8-12 \text { in and } 1.5 \text { pt of Direx on cotton taller than } 12 \text { in. Add surfactant according } \\
\text { to label. Do not add other spray additives. Compared to glyphosate alone, this } \\
\text { combination controls bigger morning glories and provides residual control of small- } \\
\text { seeded broadleaf weeds, such as pigweed. However, the tank mix may give less grass } \\
\text { control than glyphosate alone. Do not reduce the rate of glyphosate. }\end{array}$ \\
\hline \multicolumn{3}{|r|}{ Roundup Ready Flex Cotton } \\
\hline $\begin{array}{l}\text { Glyphosate-5.5 lb/ } \\
\text { gallon formulation } \\
\text { such as Roundup } \\
\text { Weathermax } \\
\text { (22-32 oz) } \\
\text { Glyphosate-5 lb } \\
\text { (24-35 oz) } \\
\text { Glyphosate-4 lb } \\
\text { (30-44 oz) }\end{array}$ & $\begin{array}{l}\text { glyphosate } \\
(0.95-1.38 \mathrm{lb})\end{array}$ & $\begin{array}{l}\text { Roundup Ready Flex cotton allows over-the-top applications of glyphosate all season, } \\
\text { until } 7 \text { days prior to harvest, without threat of boll loss or reduced yield. There are no } \\
\text { restrictions on timing of sequential applications. Can apply as much as } 4 \text { qt of Roundup } \\
\text { Weathermax from emergence to } 60 \% \text { boll crack, but no more than } 5.3 \text { qt per acre pre- } \\
\text { season. Some glyphosate brands have been shown to cause leaf burn when applied } \\
\text { late in the season. Do not combine the instructions in this section with those for } \\
\text { Roundup Ready cotton. }\end{array}$ \\
\hline
\end{tabular}


Table 4. Estimated effectiveness of recommended herbicides on common weeds in Florida cotton. ${ }^{1}$

\begin{tabular}{|c|c|c|c|c|c|}
\hline \multirow[t]{3}{*}{ Weed Name } & $\begin{array}{l}\text { Treflan or } \\
\text { Prowl }\end{array}$ & Solicam & $\begin{array}{l}\text { Cotoran or } \\
\text { Meturon }\end{array}$ & $\begin{array}{c}\text { Karmex, Direx, } \\
\text { Diuron }\end{array}$ & Command \\
\hline & \multicolumn{5}{|c|}{ Time of Application } \\
\hline & PPI & PPI & PRE & PRE & PRE \\
\hline amaranth, Palmer & $\mathrm{F}$ & $\mathrm{F}$ & G & $\mathrm{F}$ & $P$ \\
\hline anoda, spurred & G & - & $\mathrm{P}$ & $\mathrm{P}$ & E \\
\hline barnyardgrass & $\mathrm{E}$ & $\mathrm{E}$ & G & $\mathrm{F}$ & $\mathrm{E}$ \\
\hline beggarweed, Florida & $\mathrm{P}$ & G & G & G & $F-G$ \\
\hline bermudagrass & $\mathrm{P}$ & $\mathrm{P}$ & $\mathrm{P}$ & $\mathrm{P}$ & $P$ \\
\hline burgherkin & $\mathrm{P}$ & G & $F-G$ & $\mathrm{~F}$ & $\mathrm{P}$ \\
\hline carpetweed & G & G & G & G & G \\
\hline citronmelon & $\mathrm{P}$ & $\mathrm{F}$ & $F-G$ & $\mathrm{~F}$ & $\mathrm{P}$ \\
\hline cocklebur, common & $\mathrm{P}$ & $P$ & G & $P$ & $\mathrm{~F}$ \\
\hline copperleaf, hophornbeam & $\mathrm{P}$ & E & E & E & E \\
\hline cowpea & $\mathrm{P}$ & $P$ & $\mathrm{P}$ & - & $P$ \\
\hline crabgrass & $\mathrm{E}$ & E & G & G & G \\
\hline crotalaria, showy & $\mathrm{P}$ & - & G & G & - \\
\hline croton, tropic & $\mathrm{P}$ & G-E & G & - & E \\
\hline crowfootgrass & E & G & G & G & $\mathrm{F}$ \\
\hline dayflower, spreading & $\mathrm{P}$ & - & $\mathrm{P}$ & $P$ & - \\
\hline eclipta & $\mathrm{P}$ & $\mathrm{F}$ & $\mathrm{F}$ & $\mathrm{F}$ & $\mathrm{F}$ \\
\hline goosegrass & $\mathrm{E}$ & G & G & G & G \\
\hline jimsonweed & $\mathrm{P}$ & $\mathrm{F}$ & G & G-E & G \\
\hline johnsongrass (rhizome) & $\mathrm{P}$ & $\mathrm{P}$ & $\mathrm{P}$ & $\mathrm{P}$ & $\mathrm{P}$ \\
\hline johnsongrass (seedling) & G & G & $\mathrm{F}$ & $\mathrm{F}$ & G \\
\hline lambsquarters, common & G & G & $\mathrm{E}$ & G & G \\
\hline morning glory, cypressvine & $\mathrm{P}$ & $\mathrm{F}$ & G & - & $F-G$ \\
\hline morning glory, entireleaf & $\mathrm{P}$ & $\mathrm{F}$ & G & - & $F-G$ \\
\hline morning glory, ivyleaf & $\mathrm{P}$ & $\mathrm{F}$ & G & - & $F-G$ \\
\hline morning glory, pitted & $\mathrm{P}$ & $\mathrm{F}$ & G & - & $F-G$ \\
\hline morning glory, purple & $\mathrm{P}$ & $\mathrm{F}$ & G & - & $F-G$ \\
\hline morning glory, smallflower & $\mathrm{P}$ & $\mathrm{F}$ & G & - & $F-G$ \\
\hline morning glory, tall & $\mathrm{P}$ & $\mathrm{F}$ & G & - & $F-G$ \\
\hline nutsedge, purple & $\mathrm{P}$ & $\mathrm{P}-\mathrm{F}$ & $\mathrm{P}$ & $\mathrm{P}$ & $\mathrm{P}$ \\
\hline nutsedge, yellow & $\mathrm{P}$ & $\mathrm{P}-\mathrm{F}$ & $\mathrm{P}$ & $P$ & $P$ \\
\hline panicum, fall & E & G & $\mathrm{P}$ & $P$ & G \\
\hline panicum, Texas & $\mathrm{E}$ & $\mathrm{P}-\mathrm{F}$ & $\mathrm{P}$ & $\mathrm{P}$ & $\mathrm{F}$ \\
\hline pigweed, redroot & $\mathrm{E}$ & $F-G$ & $E$ & E & $\mathrm{P}$ \\
\hline pigweed, smooth & $\mathrm{E}$ & $F-G$ & G-E & G & $P$ \\
\hline poinsettia, wild & $\mathrm{P}$ & $\mathrm{P}$ & $\mathrm{P}$ & $P$ & $\mathrm{~F}$ \\
\hline purslane, common & $\mathrm{E}$ & E & $\mathrm{F}$ & E & G \\
\hline pusley, Florida & $\mathrm{E}$ & G-E & G & G & G \\
\hline ragweed, common & $\mathrm{P}$ & G & G & G & G \\
\hline redweed & $\mathrm{P}$ & G & G & G & G \\
\hline sandbur, field & $E$ & - & G & G & $F-G$ \\
\hline senna, coffee & $\mathrm{P}$ & $\mathrm{P}$ & $\mathrm{P}$ & P & $\mathrm{F}$ \\
\hline
\end{tabular}




\begin{tabular}{|c|c|c|c|c|c|}
\hline \multirow[t]{3}{*}{ Weed Name } & $\begin{array}{l}\text { Treflan or } \\
\text { Prowl }\end{array}$ & Solicam & $\begin{array}{l}\text { Cotoran or } \\
\text { Meturon }\end{array}$ & $\begin{array}{c}\text { Karmex, Direx, } \\
\text { Diuron }\end{array}$ & Command \\
\hline & \multicolumn{5}{|c|}{ Time of Application } \\
\hline & PPI & PPI & PRE & PRE & PRE \\
\hline sesbania, hemp & $\mathrm{P}$ & $P$ & $\mathrm{~F}$ & $\mathrm{P}$ & $\mathrm{F}$ \\
\hline sicklepod & $\mathrm{P}$ & $\mathrm{F}$ & G & $\mathrm{P}$ & $\mathrm{P}$ \\
\hline sida, prickly & $\mathrm{P}$ & $\mathrm{E}$ & $\mathrm{E}$ & $\mathrm{F}$ & G \\
\hline signalgrass, broadleaf & E & G & G & G & E \\
\hline smartweed, Pennsylvania & $\mathrm{P}$ & $\mathrm{F}$ & $\mathrm{P}$ & $\mathrm{F}$ & $\mathrm{E}$ \\
\hline spurge, spotted & $\mathrm{P}$ & $\mathrm{F}$ & $\mathrm{P}$ & $\mathrm{F}$ & $\mathrm{P}$ \\
\hline starbur, bristly & $\mathrm{P}$ & - & G & $P$ & $P$ \\
\hline velvetleaf & $\mathrm{P}$ & $\mathrm{F}$ & $\mathrm{P}$ & $\mathrm{F}$ & $\mathrm{E}$ \\
\hline \multicolumn{6}{|c|}{$\begin{array}{l}\text { 'Estimated effectiveness based on rates recommended in this report. Effectiveness may vary depending on factors such as herbicide rate, siz } \\
\text { of weeds, time of application, soil type, and weather conditions. } \\
\text { Weed Control Symbols: } E=90 \%-100 \% \text { control; } G=80 \%-90 \% \text { control; } F=60 \%-80 \% \text { control; } P=\text { less than } 60 \% \text { control; }-=\text { insufficient } \\
\text { observations. } \\
\text { Time of Application Symbols: } P P I=\text { preplant incorporated; PRE = preemergence }\end{array}$} \\
\hline
\end{tabular}

Table 5. Estimated effectiveness of recommended herbicides on common weeds in Florida cotton (continued). ${ }^{1}$

\begin{tabular}{|c|c|c|c|c|c|c|}
\hline \multirow[t]{3}{*}{ Weed Name } & $\begin{array}{l}\text { Dual Magnum } \\
\text { (and others) }\end{array}$ & Envoke & Liberty $^{2}$ & Glyphosate $^{3}$ & $\begin{array}{l}\text { Poast, Fusilade } \\
\text { DX, Assure II, } \\
\text { Select }\end{array}$ & Staple \\
\hline & \multicolumn{6}{|c|}{ Time of Application } \\
\hline & РOT & РOT & РОт & РОт & РОT & РОт \\
\hline amaranth, Palmer & G & $\mathrm{P}-\mathrm{F}$ & $\mathrm{F}$ & $\mathrm{E}$ & $\mathrm{P}$ & G \\
\hline anoda, spurred & - & - & $\mathrm{F}$ & G & $\mathrm{P}$ & $\mathrm{E}$ \\
\hline barnyardgrass/jungle rice & G & $P$ & $\mathrm{P}-\mathrm{F}$ & $\mathrm{F}$ & G-E & $P$ \\
\hline beggarweed, Florida & $\mathrm{P}$ & G & G & $\mathrm{F}-\mathrm{G}$ & $\mathrm{P}$ & G \\
\hline bermudagrass & $\mathrm{P}$ & $\mathrm{P}$ & $\mathrm{P}$ & $F-G$ & G & $\mathrm{P}$ \\
\hline burgherkin & $\mathrm{P}$ & - & G & G & $\mathrm{P}$ & G \\
\hline carpetweed & G-E & - & G & $\mathrm{E}$ & $\mathrm{P}$ & G \\
\hline citronmelon & $P$ & - & G & $E$ & $P$ & - \\
\hline cocklebur, common & $\mathrm{P}$ & $E$ & G-E & $E$ & $\mathrm{P}$ & G \\
\hline copperleaf, hophornbeam & $\mathrm{P}$ & - & $\mathrm{F}-\mathrm{G}$ & G & $\mathrm{P}$ & $\mathrm{P}$ \\
\hline cowpea & $P$ & - & $F-G$ & G-E & $\mathrm{P}$ & G \\
\hline crabgrass & $\mathrm{E}$ & $\mathrm{P}$ & G & $E$ & $\mathrm{E}$ & $\mathrm{P}$ \\
\hline crotalaria, showy & $\mathrm{P}$ & - & $\mathrm{F}-\mathrm{G}$ & G & $\mathrm{P}$ & $\mathrm{P}$ \\
\hline croton, tropic & $P$ & $\mathrm{P}-\mathrm{F}$ & G & $E$ & $\mathrm{P}$ & $P$ \\
\hline crowfootgrass & G-E & $\mathrm{P}$ & G & $E$ & $\mathrm{E}$ & $\mathrm{P}$ \\
\hline dayflower, spreading & G-E & $\mathrm{P}-\mathrm{F}$ & $\mathrm{F}$ & $\mathrm{F}$ & $\mathrm{P}$ & $\mathrm{G}-\mathrm{E}$ \\
\hline eclipta & $\mathrm{P}-\mathrm{F}$ & G & $F-G$ & G & $P$ & - \\
\hline goosegrass & G-E & $\mathrm{P}$ & $F-G$ & $E$ & $\mathrm{E}$ & $\mathrm{P}$ \\
\hline jimsonweed & $\mathrm{P}$ & $\mathrm{P}$ & $\mathrm{E}$ & G-E & $\mathrm{P}$ & $\mathrm{E}$ \\
\hline johnsongrass (rhizome) & $\mathrm{P}$ & $\mathrm{P}$ & $\mathrm{P}$ & $\mathrm{E}$ & G-E & $P$ \\
\hline johnsongrass (seedling) & $\mathrm{F}$ & $\mathrm{F}$ & $\mathrm{P}-\mathrm{F}$ & $\mathrm{E}$ & $\mathrm{E}$ & $\mathrm{P}$ \\
\hline lambsquarters, common & $F-G$ & G & $\mathrm{E}$ & G-E & $P$ & $P$ \\
\hline morning glory, cypressvine & $\mathrm{P}$ & G & G-E & $F-G$ & $\mathrm{P}$ & G \\
\hline morning glory, entireleaf & $\mathrm{P}$ & G & G-E & $\mathrm{F}-\mathrm{G}$ & $\mathrm{P}$ & G \\
\hline morning glory, ivyleaf & $P$ & G & $\mathrm{G}-\mathrm{E}$ & $F-G$ & $P$ & G \\
\hline
\end{tabular}




\begin{tabular}{|c|c|c|c|c|c|c|}
\hline \multirow[t]{3}{*}{ Weed Name } & $\begin{array}{l}\text { Dual Magnum } \\
\text { (and others) }\end{array}$ & Envoke & Liberty $^{2}$ & Glyphosate $^{3}$ & $\begin{array}{l}\text { Poast, Fusilade } \\
\text { DX, Assure II, } \\
\text { Select }\end{array}$ & Staple \\
\hline & \multicolumn{6}{|c|}{ Time of Application } \\
\hline & РОT & РOT & РОт & РОT & РOT & РОT \\
\hline morning glory, pitted & $\mathrm{P}$ & G & G-E & $\mathrm{F}-\mathrm{G}$ & $P$ & G \\
\hline morning glory, purple & $\mathrm{P}$ & G & G-E & $\mathrm{F}-\mathrm{G}$ & $\mathrm{P}$ & G \\
\hline morning glory, smallflower & $\mathrm{P}$ & $\mathrm{P}$ & $\mathrm{G}-\mathrm{E}$ & $\mathrm{F}-\mathrm{G}$ & $\mathrm{P}$ & G \\
\hline morning glory, tall & $\mathrm{P}$ & G & $\mathrm{G}-\mathrm{E}$ & $\mathrm{F}-\mathrm{G}$ & $\mathrm{P}$ & G \\
\hline nutsedge, purple & $\mathrm{P}$ & $E$ & $\mathrm{P}-\mathrm{F}$ & G & $\mathrm{P}$ & $\mathrm{P}$ \\
\hline nutsedge, yellow & $\mathrm{F}-\mathrm{G}$ & $\mathrm{E}$ & $\mathrm{P}-\mathrm{F}$ & $\mathrm{F}$ & $\mathrm{P}$ & $\mathrm{P}$ \\
\hline panicum, fall & G & $\mathrm{P}$ & $\mathrm{G}-\mathrm{E}$ & $\mathrm{E}$ & $\mathrm{E}$ & $\mathrm{P}$ \\
\hline panicum, Texas & $\mathrm{P}$ & $\mathrm{P}$ & G-E & $E$ & G-E & $\mathrm{P}$ \\
\hline pigweed, redroot & G & G & $\mathrm{F}$ & $\mathrm{E}$ & $P$ & $\mathrm{E}$ \\
\hline pigweed, smooth & G & G & $\mathrm{F}$ & $E$ & $\mathrm{P}$ & $E$ \\
\hline poinsettia, wild & $\mathrm{P}$ & G & G & $\mathrm{G}-\mathrm{E}$ & $\mathrm{P}$ & $\mathrm{F}-\mathrm{G}$ \\
\hline purslane, common & - & - & $E$ & $E$ & $\mathrm{P}$ & $\mathrm{F}$ \\
\hline pusley, Florida & $\mathrm{G}-\mathrm{E}$ & $\mathrm{P}$ & $\mathrm{F}-\mathrm{G}$ & $\mathrm{P}-\mathrm{F}$ & $\mathrm{P}$ & $\mathrm{P}-\mathrm{F}$ \\
\hline ragweed, common & $\mathrm{P}$ & G & $\mathrm{E}$ & $\mathrm{E}$ & $\mathrm{P}$ & $\mathrm{P}$ \\
\hline redweed & $\mathrm{P}$ & G & $\mathrm{E}$ & $\mathrm{E}$ & $\mathrm{P}$ & G \\
\hline sandbur, field & G & $\mathrm{P}$ & $\mathrm{E}$ & $\mathrm{E}$ & $\mathrm{E}$ & $\mathrm{P}$ \\
\hline senna, coffee & $\mathrm{P}$ & - & $E$ & $E$ & $\mathrm{P}$ & $E$ \\
\hline sesbania, hemp & $\mathrm{P}$ & - & $\mathrm{P}-\mathrm{F}$ & $\mathrm{P}-\mathrm{F}$ & $\mathrm{P}$ & $\mathrm{E}$ \\
\hline sicklepod & $\mathrm{P}$ & $\mathrm{E}$ & $E$ & $E$ & $\mathrm{P}$ & $\mathrm{P}-\mathrm{F}$ \\
\hline sida, prickly & $\mathrm{P}$ & $\mathrm{P}$ & G & G & $\mathrm{P}$ & $\mathrm{F}$ \\
\hline signalgrass, broadleaf & $\mathrm{F}$ & $\mathrm{P}$ & $\mathrm{E}$ & $\mathrm{E}$ & $\mathrm{E}$ & $\mathrm{P}$ \\
\hline smartweed, Pennsylvania & $\mathrm{P}$ & G & G & G & $\mathrm{P}$ & $E$ \\
\hline spurge, spotted & $\mathrm{P}$ & - & G & G & $\mathrm{P}$ & $\mathrm{F}$ \\
\hline starbur, bristly & $\mathrm{P}$ & G & G & G & $\mathrm{P}$ & G \\
\hline velvetleaf & $\mathrm{P}$ & - & G & G & $P$ & $E$ \\
\hline \multicolumn{7}{|c|}{$\begin{array}{l}{ }^{1} \text { Estimated effectiveness based on rates recommended in this report. Effectiveness may vary depending on factors such as herbicide rate, size } \\
\text { of weeds, time of application, soil type, and weather conditions. } \\
\text { Weed Control Symbols: } E=90 \%-100 \% \text { control; } G=80 \%-90 \% \text { control; } F=60 \%-80 \% \text { control; P = less than } 60 \% \text { control; - = insufficient } \\
\text { observations. } \\
\text { Time of Application Symbols: POT = postemergence over-the-top. } \\
{ }^{2} \text { For use on Liberty Link varieties only. } \\
{ }^{3} \text { For use on Roundup Ready varieties only. } \\
{ }^{4} \text { Dual Magnum is applied POT to cotton. However, Dual Magnum will not control emerged weeds. Dual Magnum must contact the soil in order } \\
\text { to provide preemergence activity on germinating weed seeds. }\end{array}$} \\
\hline
\end{tabular}


Table 6. Estimated effectiveness of recommended herbicides on common weeds in Florida cotton (continued). ${ }^{1}$

\begin{tabular}{|c|c|c|c|c|c|c|c|c|}
\hline \multirow[t]{3}{*}{ Weed Name } & $\begin{array}{l}\text { Fluometuron } \\
\text { + MSMA }\end{array}$ & $\begin{array}{c}\text { Caparol + } \\
\text { MSMA }\end{array}$ & $\begin{array}{l}\text { Cobra + } \\
\text { MSMA }\end{array}$ & $\begin{array}{c}\text { Diuron or Linex } \\
+ \\
\text { MSMA }\end{array}$ & $\begin{array}{l}\text { Glyphosate } \\
\text { + Diuron }\end{array}$ & Goal & Valor & Suprend \\
\hline & \multicolumn{8}{|c|}{ Time of Application } \\
\hline & PDS & PDS & PDS & PDS & PDS & PDS & PDS & PDS \\
\hline amaranth, Palmer & G & $\mathrm{E}$ & E & G-E & $\mathrm{E}$ & $E$ & $\mathrm{E}$ & $\mathrm{E}$ \\
\hline anoda, spurred & $\mathrm{P}$ & $\mathrm{P}$ & $\mathrm{F}$ & - & - & $\mathrm{F}$ & G & - \\
\hline barnyardgrass & $\mathrm{F}$ & G & $\mathrm{F}$ & - & G & $\mathrm{F}$ & $\mathrm{F}$ & G \\
\hline beggarweed, Florida & $\mathrm{G}$ & $\mathrm{G}$ & G & $\mathrm{E}$ & $\mathrm{E}$ & $\mathrm{G}$ & $\mathrm{E}$ & G \\
\hline bermudagrass & $\mathrm{P}$ & $\mathrm{P}$ & $\mathrm{P}$ & $\mathrm{P}$ & $\mathrm{F}$ & $\mathrm{P}$ & $\mathrm{P}$ & - \\
\hline burgherkin & $P$ & G & G & G & G-E & G & $E$ & G \\
\hline carpetweed & G & G & G & - & G-E & G & $\mathrm{E}$ & - \\
\hline citronmelon & $\mathrm{P}$ & $F-G$ & $\mathrm{G}$ & $F-G$ & $\mathrm{G}$ & G & $\mathrm{G}-\mathrm{E}$ & G \\
\hline cocklebur, common & G & G & G & $\mathrm{E}$ & $\mathrm{E}$ & E & $\mathrm{E}$ & $\mathrm{E}$ \\
\hline copperleaf, hophornbeam & $\mathrm{E}$ & $\mathrm{E}$ & $\mathrm{E}$ & G & G-E & E & E & E \\
\hline cowpea & G & G & G & G & G & $F-G$ & - & - \\
\hline crabgrass & G & G & G & $\mathrm{F}-\mathrm{G}$ & G & $\mathrm{F}$ & $\mathrm{F}$ & $\mathrm{P}$ \\
\hline crotalaria, showy & G & G & G & G & G & $\mathrm{F}$ & G & G \\
\hline croton, tropic & G & G & $\mathrm{G}$ & G & $\mathrm{E}$ & $\mathrm{E}$ & $\mathrm{E}$ & - \\
\hline crowfootgrass & G & G & $\mathrm{F}$ & $F-G$ & G & $\mathrm{P}$ & $\mathrm{F}$ & - \\
\hline dayflower, spreading & $\mathrm{F}$ & $\mathrm{F}$ & $\mathrm{E}$ & - & - & - & $F-G$ & - \\
\hline eclipta & $\mathrm{F}$ & $\mathrm{F}$ & $\mathrm{F}$ & - & $\mathrm{G}$ & G & G-E & G \\
\hline goosegrass & G & G & $\mathrm{G}$ & $\mathrm{F}-\mathrm{G}$ & $\mathrm{G}$ & $\mathrm{F}$ & $\mathrm{F}$ & - \\
\hline jimsonweed & $\mathrm{E}$ & G-E & G-E & G & $\mathrm{E}$ & $\mathrm{E}$ & $\mathrm{E}$ & G \\
\hline johnsongrass (rhizome) & $P$ & $P$ & $F-G$ & $\mathrm{P}$ & G & $P$ & $P$ & $\mathrm{P}$ \\
\hline johnsongrass (seedling) & G & G & G & $\mathrm{F}$ & G & $\mathrm{F}$ & $\mathrm{F}$ & $P$ \\
\hline lambsquarters, common & G & G & $\mathrm{F}$ & G & G-E & G & $\mathrm{E}$ & G \\
\hline morning glory, cypressvine & G-E & G-E & G-E & G-E & G-E & G & $\mathrm{E}$ & G-E \\
\hline morning glory, entireleaf & G-E & G-E & G-E & G-E & G-E & G & E & G-E \\
\hline morning glory, ivyleaf & G-E & G-E & G-E & - & G-E & G & $\mathrm{E}$ & G-E \\
\hline morning glory, pitted & G-E & G-E & G-E & G-E & G-E & G & E & G-E \\
\hline morning glory, purple & G-E & G-E & G-E & G-E & G-E & G & $\mathrm{E}$ & G-E \\
\hline morning glory, smallflower & G-E & G-E & G-E & G-E & G-E & G & $\mathrm{E}$ & G-E \\
\hline morning glory, tall & G-E & G-E & G-E & G-E & G-E & G & $\mathrm{E}$ & G-E \\
\hline nutsedge, purple & $\mathrm{P}$ & $\mathrm{P}-\mathrm{F}$ & $\mathrm{P}$ & $\mathrm{F}$ & G & $P$ & $\mathrm{P}-\mathrm{F}$ & G-E \\
\hline nutsedge, yellow & $\mathrm{P}-\mathrm{F}$ & $\mathrm{P}-\mathrm{F}$ & $\mathrm{P}-\mathrm{F}$ & $\mathrm{F}$ & $\mathrm{F}$ & $\mathrm{P}$ & $\mathrm{P}-\mathrm{F}$ & E \\
\hline panicum, fall & G & G & $\mathrm{G}$ & $\mathrm{F}-\mathrm{G}$ & - & $\mathrm{F}$ & $\mathrm{F}$ & $\mathrm{E}$ \\
\hline panicum, Texas & G & G & G & $\mathrm{F}$ & G & $\mathrm{F}$ & $\mathrm{F}$ & - \\
\hline pigweed, redroot & G & $\mathrm{E}$ & $\mathrm{E}$ & $\mathrm{E}$ & $\mathrm{E}$ & $\mathrm{E}$ & $\mathrm{E}$ & $\mathrm{E}$ \\
\hline pigweed, smooth & $\mathrm{G}$ & $\mathrm{E}$ & $\mathrm{E}$ & $\mathrm{E}$ & $\mathrm{E}$ & $\mathrm{E}$ & $\mathrm{E}$ & $\mathrm{E}$ \\
\hline poinsettia, wild & $\mathrm{F}$ & $\mathrm{P}$ & $\mathrm{G}$ & $\mathrm{P}$ & $F-G$ & $F-G$ & G & G \\
\hline purslane, common & $\mathrm{F}$ & G & G & - & E & E & E & - \\
\hline pusley, Florida & G & G & $\mathrm{G}$ & $\mathrm{F}$ & $\mathrm{F}$ & $\mathrm{F}$ & - & - \\
\hline ragweed, common & G & G & G & G & G & G & G-E & - \\
\hline redweed & G & G & G & G & $\mathrm{F}$ & $\mathrm{F}$ & - & - \\
\hline sandbur, field & G & G & G & G & $\mathrm{F}-\mathrm{G}$ & $\mathrm{F}$ & $\mathrm{F}$ & G \\
\hline
\end{tabular}




\begin{tabular}{|c|c|c|c|c|c|c|c|c|}
\hline \multirow[t]{3}{*}{ Weed Name } & $\begin{array}{l}\text { Fluometuron } \\
\text { + MSMA }\end{array}$ & $\begin{array}{c}\text { Caparol + } \\
\text { MSMA }\end{array}$ & $\begin{array}{c}\text { Cobra + } \\
\text { MSMA }\end{array}$ & $\begin{array}{c}\text { Diuron or Linex } \\
+ \\
\text { MSMA }\end{array}$ & $\begin{array}{c}\text { Glyphosate } \\
\text { + Diuron }\end{array}$ & Goal & Valor & Suprend \\
\hline & \multicolumn{8}{|c|}{ Time of Application } \\
\hline & PDS & PDS & PDS & PDS & PDS & PDS & PDS & PDS \\
\hline senna, coffee & $\mathrm{P}$ & $\mathrm{F}$ & $\mathrm{P}$ & G & G & G & $\mathrm{G}-\mathrm{E}$ & $\mathrm{F}$ \\
\hline sesbania, hemp & $P$ & $\mathrm{~F}$ & $\mathrm{~F}$ & $\mathrm{P}-\mathrm{F}$ & G & $\mathrm{F}$ & G & $\mathrm{F}$ \\
\hline sicklepod & G & $\mathrm{G}$ & $\mathrm{F}-\mathrm{G}$ & $\mathrm{G}-\mathrm{E}$ & G-E & $\mathrm{F}$ & $\mathrm{E}$ & $\mathrm{G}-\mathrm{E}$ \\
\hline sida, prickly & $\mathrm{F}$ & $\mathrm{G}$ & G & G & G-E & G & $E$ & G \\
\hline signalgrass, broadleaf & G & G & G & - & G & G & $\mathrm{F}$ & G \\
\hline smartweed, Pennsylvania & $\mathrm{P}$ & $P$ & $\mathrm{~F}$ & - & $E$ & $E$ & $E$ & - \\
\hline spurge, spotted & $\mathrm{P}$ & $\mathrm{P}$ & $E$ & G & $E$ & $\mathrm{E}$ & $E$ & - \\
\hline starbur, bristly & G & G & G & G & G & $\mathrm{F}$ & $\mathrm{G}-\mathrm{E}$ & $\mathrm{G}$ \\
\hline velvetleaf & $\mathrm{F}$ & $\mathrm{F}$ & $\mathrm{G}$ & $\mathrm{G}$ & G-E & $\mathrm{G}$ & $E$ & - \\
\hline
\end{tabular}

${ }^{1}$ Estimated effectiveness based on rates recommended in this report. Effectiveness may vary depending on factors such as herbicide rate, size of weeds, time of application, soil type, and weather conditions.

Weed Control Symbols: $E=90 \%-100 \%$ control; $G=80 \%-90 \%$ control; F $=60 \%-80 \%$ control; $P=$ less than $60 \%$ control; $-=$ insufficient observations.

Time of Application Symbols: PDS = post-directed spray. 